\title{
Implementasi Akad Murabahah Pada Pembiayaan Rumah Non Bank Di Puri Nirana Cigelam Purwakarta
}

\author{
Ratna Patmawati ${ }^{1}$, Nasrudin ${ }^{2}$ \\ ${ }^{1}$ Mahasiswa Prodi Ekonomi Syariah STIES Indonesia Purwakarta \\ ${ }^{2}$ Dosen Prodi Perbankan Syariah STIES Indonesia Purwakarta \\ Jl. Veteran No. 150-152 Ciseureuh Purwakarta 41118 Jawa Barat Indonesia \\ ${ }^{1}$ ratna_patmawati@gmail.com \\ ${ }^{2}$ nasrudin@sties-purwakarta.ac.id
}

\begin{abstract}
Intisari- Penelitian ini membahas tentang bagaimana cara penetapan Marjin Murabahah dalam akad pembelian atau pembiayaan, kendala apa yang dihadapi dalam penetapan Marjin, upaya apa saja yang dilakukan dalam penerapan Implementasi akad Murabahah pada pembiayaan rumah non bank dan bagaimana respon konsumen terhadap penerapan akad murabahah di Puri Nirana Cigelam Purwakarta. Penelitian ini menggunakan metode deskriptif kualitatif dengan menggunakan data primer dan data sekunder. Hasil penelitian menunjukan bahwa Penetepan margin dalam akad murabahah berdasarkan kesepakatan, kesepakatannya adalah 10\%, pada realitasnya margin yang didapatkan pada setiap tahun kurang dari $10 \%$. Tidak ada kendala dalam penetapan margin dalam akad murabahah yang telah diimplementasikan di Puri Nirana Cigelam, Implementasi akad murabahah dalam pembiayaan rumah non bank di Puri Nirana Cigelam yaitu penandatangan akad kedua belah pihak antara developer yang menjual rumah dan konsumen yang membeli rumah dengan kejelasan harga dan pembayaran secara flat serta penentapan margin atau keuntungan yang kedua belah pihak sama-sama menyepakati. Respon konsumen terhadap implementasi akad murabahah di Puri Nirana Cigelam banyak yang menyatakan setuju dan bagus, dengan begitu keberadaan Puri Nirana Cigelam, akad yang diterapkan di Puri Nirana Cigelam, Konsep Islami dan Value Syari'ah serta fasilitas-fasilitas yang diberikan oleh pihak PNC adalah alasan konsumen memilih membeli perumahan di Puri Nirana Cigelam.
\end{abstract}

Kata kunci- Akad murabahah, pembiayaan rumah tanpa bank.

Abstract - This study discusses how to determine the Margin Murabaha in the purchase or financing agreement, what constraints faced in the determination of Margin, what efforts are made in the implementation of Murabahah agreement on the financing of non-bank housing and how the consumer response to the application of murabahah contract in Puri Nirana Cigelam. This research uses descriptive qualitative method by using primary data and secondary data. The result of the research shows that margin acceptance in murabahah agreement based on agreement, the agreement is $10 \%$, in reality the margin obtained in every year is less than $10 \%$. There is no constraint in determining the margin in the murabaha scheme that has been implemented in Puri Nirana Cigelam, Murabahah scheme implementation in the financing of non-bank house in Puri Nirana Cigelam is signing the agreement of both parties between the developers who sell the house and the consumer who bought the house with the clarity of price and payment flat as well as the margin or profit setting that both parties agree on. Consumer response to the implementation of murabahah agreement in Puri Nirana Cigelam castle that many agree and good, average, so the existence of Puri Nirana Cigelam, akad applied in Puri Nirana Cigelam, Islamic Concepts and Value Syari'ah and facilities provided by the PNC is the reason consumers choose to buy housing in Puri Nirana Cigelam.

Keywords - Murabahah Akad, house financing without bank.

\section{Pendahuluan}

Rumah adalah struktur fisik terdiri dari ruangan, halaman dan area sekitarnya yang dipakai sebagai tempat tinggal dan sarana pembinaan keluarga. Perumahan adalah kelompok rumah yang berfungsi sebagai lingkungan tempat tinggal atau lingkungan hunian yang dilengkapi dengan prasarana dan sarana lingkungan. Pemukiman adalah bagian dari lingkungan hidup di luar kawasan lindung, baik yang berupa kawasan perkotaan maupun perdesaan yang berfungsi sebagai lingkungan tempat tinggal atau lingkungan hunian dan tempat kegiatan yang mendukung perikehidupan dan penghidupan. Satuan lingkungan pemukiman adalah kawasan perumahan dalam berbagai bentuk dan ukuran dengan penataan tanah dan ruang, prasarana dan sarana lingkungan yang terstruktur. Prasarana lingkungan adalah kelengkapan dasar fisik

${ }^{1}$ BAB I Pasal I Undang-Undang RI No.4 Tahun 1992 Tentang Perumahan dan Pemukiman lingkungan yang memungkinkan lingkungan permukiman dapat berfungsi sebagaimana mestinya. Sarana lingkungan adalah fasilitas penunjang yang berfungsi untuk penyelenggaraan dan pengembangan kehidupan ekonomi, sosial dan budaya. Utilitas umum adalah sarana penunjang untuk pelayanan lingkungan. ${ }^{1}$

Dalam pembangunan nasional yang pada hakikatnya adalah pembangunan manusia Indonesia seutuhnya dan pembangunan seluruh masyarakat Indonesia, perumahan dan pemukiman yang layak, sehat, aman, serasi, dan teratur merupakan salah satu kebutuhan dasar manusia dan merupakan faktor penting dalam peningkatan harkat dan martabat mutu kehidupan serta kesejahteraan rakyat dalam masyarakat adil dan makmur berdasarkan Pancasila dan Undang-Undang Dasar 1945. ${ }^{2}$

Dalam rangka peningkatan harkat dan martabat, mutu kehidupan dan kesejahteraan tersebut bagi setiap keluarga
2 Undang-Undang RI No.4 Tahun 1992 Tentang Perumahan dan Pemukiman 
Indonesia, pembangunan perumahan dan pemukiman sebagai bagian dari pembangunan nasional perlu terus ditingkatkan dan dikembangkan secara terpadu, terarah, berencana, dan berkesinambungan. Bahwa peningkatan dan pengembangan perumahan dan pemukiman dengan berbagai aspek permasalahannya perlu diupayakan sehingga merupakan satu kesatuan fungsional dalam wujud tata ruang fisik, kehidupan ekonomi dan sosial budaya untuk mendukung ketahanan nasional, mampu menjamin kelestarian lingkungan hidup dan meningkatkan kualitas kehidupan manusia Indonesia dalam berkeluarga, bermasyarakat, berbangsa dan bernegara.

Perumahan dan pemukiman merupakan kesatuan fungsional, sebab pembangunan perumahan harus berlandaskan suatu pola pemukiman yang menyeluruh, yaitu tidak hanya meliputi pembangunan fisik rumah saja, melainkan juga dilengkapi dengan prasarana lingkungan, sarana umum dan fasilitas sosial.

Rumah merupakan salah satu kebutuhan pokok manusia yang harus dipenuhi. Memilik rumah sendiri adalah idaman semua orang bahkan menjadi kebutuhan bagi yang sudah berkeluarga. Namun dengan harga rumah yang melambung tinggi menyebabkan kebanyakan orang tidak bisa membeli rumah secara tunai, jadi mereka mengambil jalan alternatif dengan menyewa atau dengan angsuran.

Perumahan Puri Nirana Cigelam adalah hunian yang terdiri dari alam dan elemen-elemen buatan manusia karena merupakan hunian hijau dan asli di Lingkungan Hutan Lindung, terdapat Ruko, Mini Sport Center, Site Plan, Playground, One Gate, serta rumah yang sudah siap huni tanpa perlu renovasi lagi.

Banyak cara yang ditempuh oleh masyarakat dalam memenuhi salah satu kebutuhan pokok mereka dalam hal perumahan. Maka disini "Puri Nirana Cigelam" menjembatani kepentingan penjual dan pembeli rumah dengan fasilitas kredit pemilikan rumah. ${ }^{3}$ Fasilitas Kredit Kepemilikan Rumah (KPR) muncul karena banyaknya masyarakat tidak mampu membeli rumah secara tunai. Umumnya bank konvensional menggunakan bunga dalam KPR tersebut. Namun, sistem bunga yang identik dengan riba yang dalam islam jelas diharamkan menjadikan umat muslim ragu untuk bertransaksi.

Sistem pembelian rumah yang diterapkan pada bank konvensional dengan sistem bunga (riba) meragukan masyarakat muslim untuk bertransaksi, sudah jelas Allah menghalalkan jual beli dan mengharamkan riba. Sesuai dalam firmannya Qs. Al Baqarah [2] : 275 berikut : ${ }^{4}$

"Dan Allah telah menghalalkan jual beli dan mengharamkan riba."

Munculnya produk kredit kepemilikan rumah syari'ah telah memberikan alternatif bebas dari riba (bunga). Salah satunya dengan akad Murabahah yang memberi kepastian dalam jumlah angsuran yang harus dibayar oleh nasabah setiap bulan dan sangat membantu masyarakat menengah dan kebawah yang belum bisa membeli secara tunai. Serta menghilangkan keraguan bagi masyarakat muslim yang akan membeli rumah.

Kredit Pemilikan Rumah dengan skema akad Murabahah termasuk jenis pembiayaan konsumtif yang bertujuan memiliki rumah. Pembiayaan dalam konsep ini telah diatur dalam Fatwa Dewan Syari'ah No.04/DSN-MUI/IV/2000 tanggal 1 April 2000, tentang Murabahah. Dengan adanya pembiayaan kredit pemilikan rumah syari'ah, tentunya membantu keluarga muslim untuk bisa istiqomah dalam memiliki rumah yang sesuai dengan syari'ah.

Memiliki rumah kini bukan lagi hal yang sulit, karena sudah ada fasilitas Kredit Pembelian Rumah yang diberikan oleh kalangan dari Puri Nirana Cigelam Apalagi kondisi saat ini

${ }^{3}$ 3"Cara Mudah Memahami dan Memilih KPR," artikel diakses pada 16 mei 2011 dari www.housing-estate.com

${ }^{4}$ Al-qur'an tajwid dan terjemah Departemen Agama RI ( CV Penerbit Dipenogoro,2010) sedang boomingnya KPR Syari'ah. Puri Nirana Cigelam pun hadir ditengah masyarakat dengan Akad Tanpa Riba, Tanpa Denda, Tanpa Sita dan Tanpa Akad Bermasalah. ${ }^{5}$

Pembiayaan dalam pembelian rumah di Puri Nirana Cigelam berbeda dengan perumahan syariah yang lainnya, yang melibatkan bank syariah dalam jual beli (kredit). Dalam pembiayaan rumah di Puri Nirana Cigelam dilakukan dengan transaksi akad Murabahah yang pembayarannya langsung dengan developer yaitu transaksi non bank.

Pengembangan properti berbasis syari'ah adalah bisnis inti dari Sharia Green Land. Pengembangan properti SGL berbentuk hunian dengan lingkungan islami. Pembangunan hunian di SGL terbagi menjadi 2 macam, yaitu Kawasan Hunian dan Cluster, termasuk fasilitas tambahan seperti tempat Olahraga dan Rekreasi, Tempat Beribadah, dan Kawasan Penghijauan seperti taman dan sebagainya. Saat ini, SGL sedang mengembangkan 1 Kawasan Industri yaitu Puri Nirana Cigelam dan 3 Cluster yaitu Sharia Islamic Highland, Sharia Green River, dan Pesona Giri Merak . 6

Puri Nirana Cigelam adalah hunian yang dikonsep secara Islami, ada Sharia Mart sebagai pusat perniagaan, Masjid besar 2 lantai sebagai pusat kegiatan umat dan dengan pondok tahfidz dan STP Khoiru Ummah (setingkat TK, SD, SMP, SMA) sebagai lembaga pendidikannya. Berlokasi di lokasi yang Asri dan Hijau di lingkungan hutan lindung, tetapi tetap strategis karena berada di dekat kawasan Industri BIC dan Indoteise. Akses 3 pintu tol dan hanya 3-5 menit sampai di pusat kota Purwakarta. Hanya 200mtr sampai di kantor Desa, sekolahan SD dan SMP Negeri juga hanya 700mtr dari Pondok Pesantren Hidayatullah. Selain itu juga merupakan Cluster Property pertama dengan sistem syariah, dengan angsuran flat,tanpa bunga ( bunga $0 \%$ ).

\begin{tabular}{|c|c|c|c|}
\hline Tahun & $\begin{array}{c}\text { Luas Wilayah } \\
\left(\mathrm{Km}^{2}\right)\end{array}$ & Penduduk & $\begin{array}{c}\text { Kepadatan per } \\
\mathrm{Km}^{2}\end{array}$ \\
\hline 2015 & 971,72 & 921598 & 948,42 \\
\hline 2014 & 971,72 & 910007 & 936,49 \\
\hline 2013 & 971,72 & 898001 & 924,14 \\
\hline 2012 & 971,72 & 882799 & 908,49 \\
\hline 2011 & 971,72 & 867828 & 893,08 \\
\hline
\end{tabular}

Tabel 1.2

Jumlah penduduk, Rasio Jenis Kelamin dan Rata penduduk di Kabupaten Purwakarta, 2011-2015

\begin{tabular}{|l|c|c|c|c|c|}
\hline \multicolumn{2}{|c|}{ Purwakarta, 2011-2015 } \\
\hline \multirow{2}{*}{ Tahun } & & Penduduk & Rasio & Rata-rata \\
\cline { 2 - 6 } & & & Laki-laki + & Jenis & Penduduk \\
\hline 2015 & 469180 & 452418 & 921598 & 103,70 & 4799,99 \\
\hline 2014 & 463506 & 446501 & 910007 & 103,81 & 4739,62 \\
\hline 2013 & 457578 & 440423 & 898001 & 103,90 & 4677,09 \\
\hline 2012 & 451553 & 431246 & 882799 & 104,71 & 4597,91 \\
\hline 2011 & 443912 & 423916 & 867828 & 104,72 & 4519,94 \\
\hline
\end{tabular}

5 Pernyataan dari Branch Manager Puri Nirana Cigelam tanggal 22 september 2017

${ }^{6}$ www.shariagreenlandcorp.com. diakses 26 Mei 2017 
Tabel 1.2

Jumlah penduduk, Rasio Jenis Kelamin dan Rata penduduk di Kabupaten Purwakarta, 2011-2015

\begin{tabular}{|c|c|c|c|c|c|}
\hline & & Penduduk & Rasio & Rata-rata \\
\cline { 2 - 6 } & & & Laki-1aki + & Jenis & Penduduk \\
Tahun & Laki-1aki & Perempuan & Perempuan & Kelamin & Per Desa \\
\hline 2015 & 469180 & 452418 & 921598 & 103,70 & 4799,99 \\
\hline 2014 & 463506 & 446501 & 910007 & 103,81 & 4739,62 \\
\hline 2013 & 457578 & 440423 & 898001 & 103,90 & 4677,09 \\
\hline 2012 & 451553 & 431246 & 882799 & 104,71 & 4597,91 \\
\hline 2011 & 443912 & 423916 & 867828 & 104,72 & 4519,94 \\
\hline
\end{tabular}

Penduduk Kabupaten Purwakarta berdasarkan proyeksi penduduk tahun 2015 sebanyak 921.598 jiwa yang terdiri atas 469.180 jiwa penduduk laki-laki dan 452.418 jiwa penduduk perempuan. Dibandingkan dengan proyeksi jumlah penduduk tahu 2014, penduduk Purwakarta mengalami pertumbuhan sebesar 2,32 persen dengan masing-masing persentase pertumbuhan laki-laki sebesar 1,76 persen dan pertumbuhan perempuan sebesar 2,86 persen. Sementara itu besarnya angka rasio jenis kelamin tahun 2014 penduduk laki-laki terhadap penduduk perempuan sebesar 10.,70.

Kepadatan penduduk di Kabupaten Purwakarta tahun 2015 mencapai 948 jiwa/Km2 dengan rata-rata jumlah penduduk per rumah tangga 4 orang. Kepadatan penduduk di 17 Kecamatan cukup beragam dengan kepadatan penduduk tertinggi terletak di kecamatan.

Berdasarkan gambar diatas mengenai jumlah penduduk yang setiap tahun meningkat, menyebabkan bertambahnya kebutuhan akan perumahan. Kemudian berkembangnya investasi sektor industri di Purwakarta berdampak terjadinya peningkatan migrasi masuknya penduduk ke kabupaten tersebut. peningkatan jumlah penduduk berakibat meningkatnya kebutuhan akan perumahan, sehingga areal permukiman terus berkembang ke daerahdaerah di sekitar Purwakarta. Maka dengan adanya KPR Puri Nirana Cigelam yang beralamatkan di JL. Alternatif Kota Bukit Indah - Sadang , Cigelam Purwakarta membantu masyarakat yang sedang mencari perumahan.

\section{Metodologi}

Proses untuk mendapatkan ilmu agar memiliki nilai kebenaran harus dilandasi oleh cara berpikir yang rasional berdasarkan fakta. Salah satu cara untuk mendapatkan ilmu adalah dengan penelitian. Banyak definisi tentang penelitian tergantung sudut pandang masing-masing. Sekaran, memberikan definisi penelitian sebagai penyelidikan atau investigasi yang terkelola, sistematis, berdasarkan data, kritis, objektif, dan ilmiah terhadap suatu maslah yang spesifik, yang dilakukan dengan tujuan menemukan jawaban atau solusi terikat. Adapun Karlinger, menyatakan bahwa penelitian ilmiah adalah penyelidikan yang sistematis, terkontrol, empiris, dan kritis, tentang fenomena alam, dengan dipandu oleh teori

\footnotetext{
${ }^{7}$ Dr Juliansyah Noor, SE., MM. "Metodologi Penelitian Skripsi, Tesis, Disertasi dan Karya Ilmiah" (Jakarta, Prenadamedia Group, 2011), 12.

${ }^{8}$ Dr Juliansyah Noor, SE., MM. "Metodologi Penelitian Skripsi, Tesis, Disertasi dan Karya Ilmiah" (Jakarta, Prenadamedia Group, 2011), 13.

9 Prof. Dr. Sugiyono. "Metode Penelitian Pendidikan Pendekatan Kuantitatif, Kualitatif, dan R\&D” (Bandung, Alfabeta, 2014), 3.
}

dan hipotesis tentang hubungan yang diduga terdapat antara penomena itu. ${ }^{7}$

Pengertian tersebut menyiratkan bahwa penelitian merupakan langkah sistematis dalam upaya menyelesaikan masalah untuk mengambil keputusan. Penelitian terdiri dari dua hal pokok yang merupakan satu kesatuan yang tidak dapat dipisahkan satu dengan lainnya yaitu logika berfikir dan data atau informasi yang dikumpulkan secara empiris. Logika berfikir tampak dalam langkah-langkah sistematis mulai dari pengumpulan, pengolahan, analisis, penafsiran, dan pengujian data, sampai diperolehnya suatu kesimpulan. Informasi dikatakan empiris jika sumber data menggambarkan fakta yang terjadi bukan sekedar pemikiran atau rekayasa peneliti. Data kuantitatif umumnya diperoleh melalui survei atau pertanyaan terstruktur, sedangkan kualitatif diperoleh melalui wawancara yang mendalam dan spesifik. Penelitian menggabungkan cara berfikir rasional yang didasari oleh logika/penalaran dan cara berpikir empiris yang didasari oleh fakta/realita. ${ }^{8}$

Secara umum metode penelitian diartikan sebagai cara ilmiah untuk mendapatkan data dengan tujuan dan kegunaan tertentu. ${ }^{9}$ Penelitian ini mencoba untuk melihat implementasi akad murabahah pada pembiayaan rumah non bank di puri nirana cigelam Kecamatan Babakancikao Kota Purwakarta. Oleh sebab itu metodologi yang cocok adalah dengan menggunakan metode deskriptif kualitatif.

Penelitian ini meneliti implementasi akad murabahah yang digunakan dalam proses jual beli rumah antara developer dan pembeli. Ini berarti peneliti meneliti manusia yang melakukan transaksi jual beli rumah dengan menggunakan akad murabahah yang telah di implementasikan oleh KPR Syariah Puri Nirana Cigelam.

Pendekatan penelitian Kualitatif lebih banyak ditujukan pada pembentukan teori substantif berdasarkan konsep-konsep yang timbul dari data empiris. Dalam penelitian Kualitatif, penelitian merasa "tidak tahu mengenai apa-apa yang hendak diketahuinya", sehingga desain penelitian yang dikembangkan selalu merupakan kemungkinan yang terbuka akan berbagai perubahan yang diperlukan dan lentur terhadap kondisi yang ada di lapangan pengamatannya. ${ }^{10}$

Penelitian kualitatif dilakukan pada kondisi alamiah dan bersifat penemuan. Dalam penelitian kualitatif, penelitian merupakan instrumen kunci. Oleh karena itu, peneliti harus memiliki bekal teori dan wawasan yang luas, jadi bisa bertanya, menganalisis, dan mengkonstruksi objek yang diteliti menjadi lebih jelas. Pendekatan ini lebih menekankan pada makna dan terikat nilai. Penelitian kualitatif digunakan jika masalah belum selesai, mengetahui makna yang tersembunyi, untuk memahami interaksi sosial, mengembangkan teori memastikan kebenaran data, dan meneliti sejarah perkembangan. ${ }^{11}$

Penelitian kualitatif memiliki enam jenis penelitian, yaitu deskriptif, studi kasus, biografi, fenomenologi, grounded theory, etnografi dan peneliti menggunakan jenis penelitian deskriptif yaitu penelitian yang berusaha mendeskripsikan suatu gejala, peristiwa, kejadian yang terjadi saat sekarang. Penelitian deskriptif memusatkan perhatian pada masalah aktual sebagaimana adanya pada saat penelitian berlangsung. Melalui penelitian deskriptif, peneliti harus berusaha

${ }^{10}$ Suryani. Hendryadi. "Metode Riset Kuantitatif Teori dan Aplikasi Pada Penelitian Bidang Manajemen dan Ekonomi Islam" (Jakarta, Prenademedia Group,2015), 111.

${ }^{11}$ Dr Juliansyah Noor, S.E., M.M. "Metodologi Penelitian Skripsi, Tesis, Disertasi, dan Karya Ilmiah" (Jakarta, Prenadamedia Group, 2011), 34. 
mendeskripsikan peristiwa dan kejadian yang menjadi pusat perhatian tanpa memberikan perlakuan khusus terhadap peristiwa tersebut. Variabel yang diteliti bisa tunggal (satu variabel) bisa juga lebih dari satu variabel. ${ }^{12}$

Penelitian deskriptif sesuai karakteristiknya memiliki langkah-langkah tertentu dalam pelaksanaannya. Langkahlangkah ini sebagai berikut: Diawali dengan adanya masalah, menentukan jenis informasi yang diperlukan, menentukan prosedur pengumpulan data melalui observasi atau pengamatan, pengolahan informasi atau data, dan menarik kesimpulan penelitian. ${ }^{13}$

Metode penelitian kualitatif sering disebut metode penelitian naturalistik karena penelitiannya dilakukan pada kondisi yang alamiah (natural setting); disebut juga sebagai metode etnographi, karena pada awalnya metode ini lebih banyak digunakan untuk penelitian bidang antropologi budaya; disebut sebagai metode kualitatif, karena data yang terkumpul dan analisinya lebih bersifat kualitatif. ${ }^{14}$

Metode Penelitian kualitatif adalah metode penelitian yang berlandaskan pada filsafat postpositivisme, digunakan untuk meneliti kondisi obyek yang alamiah, (sebagai lawannya adalah eksperimen) dimana peneliti adalah sebagai instrumen kunci, pengambilan sampel sumber data dilakukan secara purposive dan snowbaal, teknik pengumpulan dengan triangulasi (gabungan), analisis data bersifat induktif/kualitatif, dan hasil penelitian kualitatif lebih menekankan makna dari pada generalisasi. ${ }^{15}$

Beberapa pendapat para ahli tentang penelitian kualitatif diatas, menjadi dasar pertimbangan yang matang bagi peneliti untuk menggunakan pendekatan tersebut pada penelitian ini. Dengan menggunakan pendekatan kualitatif diharapkan penelitian yang dilakukan dapat menghasilkan data yang lengkap dan mendalam, sehingga tujuan dari penelitian ini dapat tercapai.

Definisi operasional merupakan bagian yang mendefinisikan sebuah konsep/variabel agar dapat diukur, dengan cara melihat pada dimensi (indikator) dari suatu konsep/variabel. Dimensi (indikator) dapat berupa; perilaku, aspek, atau sifat/karakteristik. Menurut Sekaran. Dengan demikian, definisi operasional tidak boleh mempunyai makna yang berbeda dengan definisi konseptual. Oleh karena itu, sebelum menyusun definisi operasional, peneliti harus membuat definisi konseptual variabel penelitian terlebih dahulu. Dengan demikian, definisi operasional bukan berarti definisi/pengertian/makna seperti yang terlihat pada teori di buku teks, namun lebih menekankan kepada hal-hal yang dapat dijadikan sebagai ukuran/indikator dari suatu variabel, dan ukuran/indikator tersebut tidak abstrak, namun mudah diukur. ${ }^{16}$

Dalam penelitian kualitatif yang bersifat holistik dan lebih menekankan kepada proses, maka penelitian kualitatif dalam melihat hubungan antara variabel pada obyek yang diteliti bersifat interaktif yaitu saling mempengaruhi (reciprocal/interaktif), sehingga tidak diketahui mana variabel independen dan dependennya. Contoh : hubungan antara iklan dan penjualan. Dalam hal ini hubungannya interaktif, artinya

\footnotetext{
${ }^{12}$ Dr Juliansyah Noor, S.E., M.M. "Metodologi Penelitian Skripsi, Tesis Disertasi, dan Karya Ilmiah" (Jakarta, Prenadamedia Group, 2011), 35.

${ }^{13}$ Dr Juliansyah Noor, S.E., M.M. "Metodologi Penelitian Skripsi, Tesis, Disertasi, dan Karya Ilmiah" (Jakarta, Prenadamedia Group, 2011), 35.

14 Prof. Dr. Sugiyono. "Metode Penelitian Pendidikan Pendekatan Kuantitatif, Kualitatif, dan R\&D” (Bandung, Alfabeta, 2014), 14.

15 Prof. Dr. Sugiyono. "Metode Penelitian Pendidikan Pendekatan Kuantitatif, Kualitatif, dan R\&D” (Bandung, Alfabeta, 2014), 15.
}

makin banyak uang yang dikeluarkan untuk iklan maka akan semakin banyak nilai penjualan, tetapi juga sebaliknya makin banyak nilai penjualan maka alokasi dana untuk iklan juga akan semakin tinggi. ${ }^{17}$

Populasi dan Sampel Penelitian, Sekaran mendefinisikan populasi sebagai keseluruhan kelompok orang, kejadian atau hal minat yang ingin peneliti investigasi. Sementara Sugiyono mendefinisikan populasi sebagai wilayah generalisir yang terdiri atas objek/subjek yang mempunyai kualitas dan karakteristik tertentu yang ditetapkan oleh peneliti untuk dipelajari dan kemudian ditarik kesimpulannya. Dengan demikian, dapat dinyatakan bahwa populasi adalah sekelompok orang, kejadian, atau benda, yang memiliki karakteristik tertentu dan dijadikan objek penelitian. ${ }^{18}$ Dalam penelitian kualitatif tidak menggunakan istilah populasi, tetapi oleh Spradley dinamakan "social situation" atau situasi sosial yang terdiri atas tiga elemen yaitu: tempat (place), pelaku (actors), dan aktivitas (activity) yang berinteraksi secara sinergis. Situasi sosial tersebut, dapat dirumah berikut keluarga dan aktivitasnya, atau orang-orang di sudut-sudut jalan yang sedang ngobrol, atau ditempat kerja, di kota, di desa, di sekolah atau wilayah suatu negara. Situasi sosial tersebut, dapat dinyatakan sebagai obyek penelitian yang ingin difahami secara lebih mendalam "apa yang terjadi" di dalamnya. Pada situasi sosial atau obyek penelitian ini peneliti dapat mengamati secara mendalam aktivitas (activity) orang-orang (actors) yang ada pada tempat (place) tertentu. Situasi sosial seperti ditunjukan pada gambar 3.1. ${ }^{19}$

Tetapi sebenarnya obyek penelitian kualitatif, juga bukan semata-mata pada situasi sosial yang terdiri atas tiga elemen tersebut, tetapi juga bisa berupa peristiwa alam, tumbuhtumbuhan, binatang, kendaraan dan sejenisnya. Seorang peneliti yang mengamati secara mendalam tentang perkembangan tumbuh-tumbuhan tertentu, kinerja mesin, menelusuri rusaknya alam, adalah merupakan proses penelitian kualitatif.

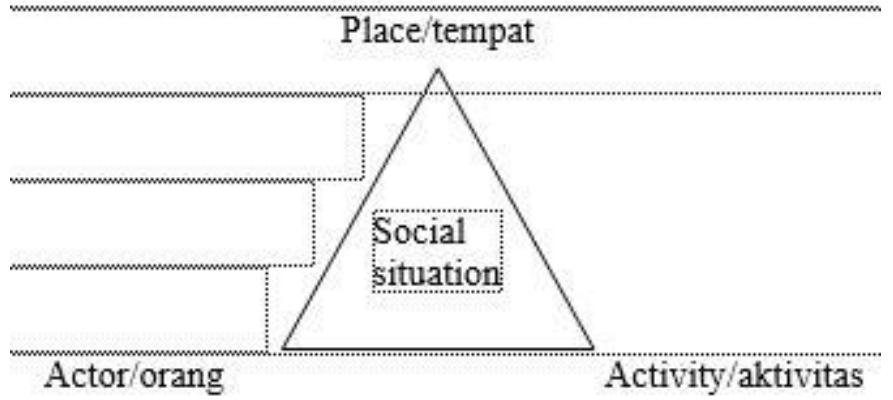

Gambar 3.1. Siuasi sosial (sosial situation)

Dalam penelitian kualitatif tidak menggunakan populasi, karena penelitian kualitatif berangkat dari penelitian tertentu yang ada pada situasi sosial tertentu dan hasil kajiannya tidak akan diberlakukan ke populasi, tetapi ditransferkan ke tempat lain pada situasi sosial yang memiliki kesamaan dengan situasi sosial pada kasus yang dipelajari. Sampel dalam penelitian kualitatif bukan dinamakan responden, tetapi sebagai nara

${ }^{16}$ Dr Juliansyah Noor, S.E., M.M. "Metodologi Penelitian Skripsi, Tesis, Disertasi, dan Karya Ilmiah" (Jakarta, Prenadamedia Group, 2011), 97.

17 Prof. Dr. Sugiyono. "Metode Penelitian Pendidikan Pendekatan Kuantitatif, Kualitatif, dan R\&D” (Bandung, Alfabeta, 2014), 19.

${ }^{18}$ Suryani. Hendryadi. "Metode Riset Kuantitatif Teori dan Aplikasi Pada Penelitian Bidang Manajemen dan Ekonomi Islam” (Jakarta, Prenademedia Group,2015), 190.

19 Prof. Dr. Sugiyono. "Metode Penelitian Pendidikan Pendekatan Kuantitatif, Kualitatif, dan R\&D” (Bandung, Alfabeta, 2014), 298. 


\section{EKSISBANK Vol. 2 No. 2 Desember 2018}

sumber, atau partisipan, informan, teman dan guru dalam penelitian. Sampel dalam penelitian kualitatif, juga bukan disebut sampel statistik, tetapi sampel teoritis, karena tujuan penelitian kualitatif adalah untuk menghasilkan teori. Sampel dalam penelitian kualitatif juga disebut sebagai sampel konstruktif, karena dengan sumber data dari sampel itu dapat dikonstruksikan fenomena yang semula masih belum jelas.

Penentuan sumber data pada orang yang diwawancarai dilakukan secara purposive, yaitu dipilih dengan pertimbangan dan tujuan tertentu. Hasil penelitian tidak akan digeneralisirkan ke populasi karena, pengambilan sampel tidak diambil secara random. Hasil penelitian dengan metode kualitatif hanya berlaku untuk kasus sosial tersebut. Hasil penelitian tersebut dapat di transferkan atau diterapkan ke situasi sosial (tempat lain), apabila situasi sosial lain tersebut memiliki kemiripan atau kesamaan dengan situasi sosial yang diteliti.

\section{A. Pengambilan Sampel}

Pengambilan sampel (sampling) adalah proses memilih sejumlah elemen secukupnya dari populasi, sehingga penelitian terhadap sampel dan pemahaman tentang sifat atau karakteristiknya akan membuat kita dapat menggeneralisasikan sifat atau karakteristik tersebut pada elemen populasi. ${ }^{20}$

Ukuran sampel atau jumlah sampel yang diambil menjadi persoalan yang penting ketika jenis penelitian yang akan dilakukan adalah penelitian yang menggunakan analisis kuantitatif. Pada penelitian yang menggunakan analisis kualitatif, ukuran sampel bukan menjadi perhatian utama, karena yang dipentingkan adalah kekayaan informasi.

Walau ukurannya kecil tetapi kaya akan informasi, maka sampelnya lebih bermanfaat. ${ }^{21}$

Beberapa pendapat tersebut yang menjelaskan tentang pengambilan sampel dalam metode kualitatif, yaitu ditujukan untuk generalisasi, sedangkan tujuan metode kualitatif sendiri yaitu untuk mengetahui suatu teori dan memahami secara mendalam, maka peneliti menggunakan teknik purposive sampling, dan snowball sampling.

Purposive sampling adalah teknik pengambilan sampel sumber data dengan pertimbangan tertentu. Pertimbangan tertentu ini misalnya orang tersebut yang dianggap paling tahu tentang apa yang kita harapkan, atau mungkin dia sebagai penguasa sehingga akan memudahkan peneliti menjelajahi obyek/situasi sosial yang diteliti. Snowball sampling adalah teknik pengambilan sampel sumber data, yang pada awalnya jumlahnya sedikit, lama-lama menjadi besar. Hal ini dilakukan karena dari jumlah sumber data yang sedikit itu tersebut belum mampu memberikan data yang lengkap, maka mencari orang lain lagi yang dapat digunakan sebagai sumber data. Dengan demikian jumlah sampel sumber data akan semakin besar, seperti bola salju yang menggelinding, lama-lama menjadi besar. $^{22}$

Lincoln dan Guba mengemukakan bahwa "Naturalistic sampling is, then, very differentfrom conventional sampling. It is based on informational, not statistical, considerations. Its pupose is to maximize information, not to facilitate generalization". Penentuan sampel dalam penelitian kualitatif (naturalistik) sangat berbeda dengan penentuan sampel dalam penelitian konvensional (kuantitatif). Penentuan sampel dalam

\footnotetext{
${ }^{20}$ Dr Juliansyah Noor, S.E., M.M. "Metodologi Penelitian Skripsi, Tesis, Disertasi, dan Karya Ilmiah" (Jakarta, Prenadamedia Group, 2011), 148

${ }^{21}$ Suryani. Hendryadi. "Metode Riset Kuantitatif Teori dan Aplikasi Pada Penelitian Bidang Manajemen dan Ekonomi Islam" (Jakarta, Prenademedia Group,2015), 193.
}

penelitian kualitatif tidak didasarkan perhitungan statistik. Sampel yang dipilih berfungsi untuk mendapatkan informasi yang maksimum, bukan untuk digeneralisirkan. ${ }^{23}$

Jadi, penentuan sampel dalam penelitian kualitatif dilakukan saat peneliti mulai memasuki lapangan dan selama penelitian berlangsung (emergent sampling design). Caranya yaitu, peneliti memilih orang tertentu yang mempertimbangkan akan memberikan data yang diperlukan; selanjutnya berdasarkan data atau informasi yang diperoleh dari sampel sebelumnya itu, peneliti dapat menetapkan sampel lainnya yang dipertimbangkan akan memberikan data lebih lengkap. Praktek seperti inilah yang disebut sebagai "serial selection of sample units" (Lincoln dan Guba, 1985), atau dalam kata-kata Bogdan dan Biklen. Dinamakan "snowball sampling technique". Unit sampel yang dipilih makin terarah sejalan dengan makin terarahnya fokus penelitian. Proses ini dinamakan Bogdan dan Biklen sebagai "continuos adjusment of 'focusing of the sample".

Dalam proses penentuan sampel seperti dijelaskan di atas, berapa besar sampel tidak bisa ditentukan sebelumnya. Seperti telah dikutip di atas, dalam sampel purposive, besar sampel ditentukan oleh pertimbangan informasi. Dalam hubungan ini S. Nasution menjelaskan bahwa penentuan unit sampel (responden) Dianggap telah memadai apabila telah sampai kepada taraf "redundancy" (datanya telah jenuh, ditambah sampel lagi tidak memberikan informasi baru), artinya bahwa dengan menggunakan sumber data yang selanjutnya boleh dikatakan tidak lagi diperoleh tambahan informasi baru yang berarti. ${ }^{24}$

Dalam proposal penelitian kualitatif, sampel sumber data yang dikemukakan masih bersifat sementara. Namun demikian pembuatan proposal perlu menyebutkan siapa-siapa yang kemungkinan akan digunakan menjadi sumber data. Dan pada penelitian ini peneliti akan meneliti tentang implementasi akad murabahah di Puri Nirana Cigelam, dan sumber datanya adalah orang yang bertransaksi dalam akad murabahah tersebut.

Populasi dalam penelitian ini yaitu tempatnya di Puri Nirana Cigelam, orang yang akan menjadi sumbernya yaitu developer, marketing, staf Puri Nirana Cigelam serta warga Puri Nirana Cigelam, dan aktivitas yang akan diteliti yaitu transaksi jual beli rumah dengan menggunakan akad murabahah. Kemudian sampel pada penelitian ini adalah Developer Puri Nirana Cigelam.

Teknik pengambilan sampel sumber data dalam penelitian kualitatif yang bersifat purposive dan snowball itu dapat digambarkan seperti gambar 3.2 berikut.

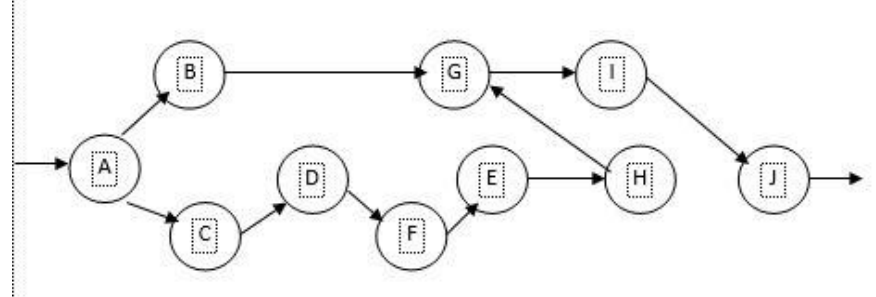

Gambar 3.2. Proses pengambilan sampel sumber data dalam penelitian kualitatif, purposive dan snowball

22 Prof. Dr. Sugiyono. "Metode Penelitian Pendidikan Pendekatan Kuantitatif, Kualitatif, dan R\&D” (Bandung, Alfabeta, 2014), 300.

23 Prof. Dr. Sugiyono. "Metode Penelitian Pendidikan Pendekatan Kuantitatif, Kualitatif, dan R\&D” (Bandung, Alfabeta, 2014), 301.

24 Prof. Dr. Sugiyono. "Metode Penelitian Pendidikan Pendekatan Kuantitatif, Kualitatif, dan R\&D” (Bandung, Alfabeta, 2014), 302. 


\section{EKSISBANK Vol. 2 No. 2 Desember 2018}

Berdasarkan gambar 3.2 tersebut dapat dijelaskan sebagai berikut. Penelitian telah merencanakan A sebagai orang pertama sebagai sumber data. Informan awal ini sebaiknya dipilih orang yang bisa "membukakan pintu" untuk mengenali keseluruhan medan secara luas (mereka yang tergolong gatekeepers/penjaga gawang dan knowledgeable informant/informan yang cerdas). Selanjutnya oleh A disarankan ke B dan C. Dari C dan B belum memperoleh data yang lengkap, maka peneliti ke F dan G. dari F dan $\mathrm{G}$ belum memperoleh data yang akurat, maka peneliti pergi ke $\mathrm{E}$, selanjutnya ke H, ke G, ke I dan terakhir ke J. Setelah sampai J data sudah jenuh, sehingga sampel sumber data sudah mencukupi, dan tidak perlu menambah sampel yang baru. ${ }^{25}$

\subsection{Sumber dan Teknik Pengumpulan Data}

\section{A. Sumber Data}

Yang dimaksud dengan sumber data dalam penelitian adalah subjek dari mana data dapat diperoleh. Apabila peneliti menggunakan kuesioner atau wawancara dalam pengumpulan datanya, maka sumber data disebut responden, yaitu orang yang merespon atau menjawab pertanyaan peneliti, baik pertanyaan tertulis atau lisan. ${ }^{26}$

Apabila peneliti menggunakan teknik observasi, maka sumber datanya bisa berupa benda, gerak atau proses sesuatu. Peneliti yang mengamati tumbuhnya jagung, sumber datanya adalah jagung, sedang objek penelitiannya adalah pertumbuhan jagung. Apabila peneliti menggunakan dokumentasi, maka dokumen atau catatanlah yang menjadi sumber data, sedang isi catatan subjek penelitian atau variabel penelitian. ${ }^{27}$

Dalam penelitian ini subyeknya terbatas pada suatu lembaga bukan bank yaitu KPRS Puri Nirana Cigelam, dan obyeknya adalah implementasi pada pembiayaan rumah berdasarkan akad murabahah.

Dalam melakukan penelitian ini data-data yang diperlukan diperoleh dari dua sumber yaitu :

1. Data primer, adalah data yang dikumpulkan dan diolah sendiri oleh suatu organisasi atau perorangan langsung dari obyeknya. Pengumpulan data tersebut dilakukan secara khusus untuk mengatasi masalah riset yang sedang diteliti.

2. Data sekunder, adalah data yang diperoleh dalam bentuk yang sudah jadi, sudah dikumpulkan dan diolah oleh pihak lain, biasanya sudah dalam bentuk publikasi. Data semacam ini sudah dikumpulkan pihak lain untuk tujuan tertentu yang bukan demi keperluan riset yang sedang dilakukan peneliti saat ini secara spesifik. ${ }^{28}$

Peneliti menggunakan data primer yaitu data yang diperoleh dari hasil wawancara dan observasi langsung dengan pihakpihak yang terkait dengan produk pembiayaan rumah syariah dengan menggunakan akad murabahah seperti developer, nasabah, dan staf di Puri Nirana Cigelam seperti bagian marketing pembiayaan. Data sekunder penelitian peneliti dapatkan dari sumber buku, web resmi Puri Nirana Cigelam, web resmi Sharia Green Land, dokumen pribadi, dokumen resmi Puri Nirana Cigelam dan lain-lain.

25 Prof. Dr. Sugiyono. "Metode Penelitian Pendidikan Pendekatan Kuantitatif, Kualitatif, dan R\&D” (Bandung, Alfabeta, 2014), 303.

${ }^{26}$ Prof. Dr. Suharsimi Arikunto. "Prosedur Penelitian Suatu Pendekatan Praktik” (Jakarta, PT Rineka Cipta, Cetakan ke 15, 2013), 172.

${ }^{27}$ Prof. Dr. Suharsimi Arikunto. "Prosedur Penelitian Suatu Pendekatan Praktik” (Jakarta, PT Rineka Cipta, Cetakan ke 15, 2013), 172.

${ }^{28}$ Suryani. Hendryadi. "Metode Riset Kuantitatif Teori dan Aplikasi Pada Penelitian Bidang Manajemen dan Ekonomi Islam" (Jakarta, Prenademedia Group,2015), 171.

\section{B. Teknik Pengumpulan Data}

Teknik pengumpulan data merupakan cara mengumpulkan data yang dibutuhkan untuk menjawab rumusan masalah penelitian. Umumnya cara mengumpulkan data dapat menggunakan teknik: wawancara (interview), angket (questionnaire), pengamatan (observation), studi dokumentasi, dan Focus Group Discussion (FGD). ${ }^{29}$

Pada penelitian kali ini peneliti menggunakan jenis penelitian kualitatif maka data yang diperoleh haruslah mendalam, jelas dan spesifik. Peneliti menggunakan teknik pengumpulan data melalui observasi, wawancara, angket, dokumentasi dan gabungan/triangulasi.

\section{Observasi}

Nasution (1988) menyatakan bahwa, observasi adalah dasar semua ilmu pengetahuan. Para ilmuan hanya dapat bekerja berdasarkan data, yaitu fakta mengenai dunia kenyataan yang diperoleh melalui observasi. Data itu dikumpulkan dan sering dengan bantuan berbagai alat yang sangat canggih, sehingga benda-benda yang sangat kecil (proton dan elektron) maupun yang sangat jauh (benda ruang angkasa) dapat diobservasi dengan jelas.

Marshall (1995) menyatakan bahwa "tharough observation, the researcher learn about behavior and the meaning attached to those behavior". Melalui observasi, peneliti belajar tentang perilaku, dan makna dari perilaku tersebut.

Sanafiah Faisal (1990) mengklasifikasikan observasi menjadi observasi berpartisipasi (participant observation), observasi secara terang-terangan dan tersamar (overt observation and covert observation), dan observasi yang tidak berstruktur (unstructured observation). Selanjutnya Spradley, dalam Susan Stainback (1988) membagi observasi berpartisipasi menjadi empat, yaitu pasive participation, moderate participation, active participation, dan complete participation. ${ }^{30}$

Dalam hal ini peneliti memilih observasi terus terang atau tersamar, peneliti dalam melakukan pengumpulan data menyatakan terus terang kepada sumber data, bahwa peneliti sedang melakukan penelitian. Jadi mereka yang diteliti mengetahui sejak awal sampai akhir tentang aktivitas peneliti. Tetapi pada suatu saat peneliti juga tidak terus terang atau tersamar dalam observasi, hal ini untuk menghindari kalau suatu data yang dicari merupakan data yang masih dirahasiakan. Kemungkinan kalau dilakukan terus terang, maka peneliti tidak akan diijinkan untuk melakukan observasi.

\section{Wawancara}

Wawancara digunakan sebagai teknik pengumpulan data apabila peneliti ingin melaukan studi pendahuluan untuk menemukan permasalahan yang harus diteliti.

Dan juga apabila peneliti ingin mengatahui hal-hal dari responden yang lebih mendalam dan jumlah respondennya sedikit/kecil. ${ }^{31}$

Wawancara merupakan salah satu teknik pengumpulan data yang dilakukan dengan berhadapan secara langsung dengan yang diwawancarai tetapi dapat juga diberikan daftar

\footnotetext{
${ }^{29}$ Dr Juliansyah Noor, S.E., M.M. "Metodologi Penelitian Skripsi, Tesis, Disertasi, dan Karya Ilmiah" (Jakarta, Prenadamedia Group, 2011), 138

30 Prof. Dr. Sugiyono. "Metode Penelitian Pendidikan Pendekatan Kuantitatif, Kualitatif, dan R\&D” (Bandung, Alfabeta, 2014), 310.

31 Prof. Dr. Sugiyono. "Metode Penelitian Administrasi" (Bandung, Alfabeta, Cetakan ke-23, 2016), 157.
} 


\section{EKSISBANK Vol. 2 No. 2 Desember 2018}

pertanyaan dahulu untuk dijawab pada kesempatan lain. Wawancara merupakan alat re-cheking atau pembuktian terhadap informasi atau keterangan yang diperoleh sebelumnya. Teknik wawancara yang digunakan penelitian kualitatif adalah wawancara mendalam. Wawancara mendalam (in-depth interview) adalah proses memperoleh keterangan untuk tujuan penelitian dan cara tanya jawab sambil bertatap muka antara pewawancara dengan informan atau orang yang diwawancarai, dengan atau tanpa menggunakan pedoman (guide) wawancara, dimana pewawancara dan informan terlibat dalam kehidupan sosial yang relatif lama. ${ }^{32}$

lincoln and Guba dalam Sanapiah Faisal, mengemukakan ada tujuh langkah dalam penggunaan wawancara untuk mengumpulkan data dalam penelitian kualitatif, yaitu:

1. Menetapkan kepada siapa wawancara itu akan dilakukan

2. Menyiapkan pokok-pokok masalah yang akan menjadi bahan pembicaraan

3. Mengawai atau membuka alur wawancara

4. Melangsungkan alur wawancara

5. Mengkonfirmasikan ikhtisari hasil wawancara dan mengakhirinya

6. Menuliskan hasil wawancara ke dalam catatan lapangan

7. Mengidentifikasikan tindak lanjut hasil wawancara yang telah diperoleh

\section{Kuesioner (Angket)}

Kuesioner merupakan teknik pengumpulan data yang dilakukan dengan cara memberi seperangkat pertanyaan atau pernyataan tertulis kepada responden untuk dijawabnya. Kuesioner merupakan teknik pengumpulan data yang efisien bila peneliti tahu dengan pasti variabel yang akan diukur dan tahu apa yang bisa diharapkan dari responden. Selain itu, kuesioner juga cocok digunakan bila jumlah responden cukup besar dan tersebar diwilayah yang luas . Kuesioner dapat berupa pertanyaan/pernyataan tertutup atau terbuka, dapat diberikan kepada responden secara langsung atau dikirim melalui pos atau internet. ${ }^{33}$

Bila penelitian dilakukan pada lingkup yang tidak terlalu luas, sehingga kuesioner dapat diantarkan langsung dalam waktu tidak terlalu lama, maka pengiriman angket kepada responden tidak perlu melalui pos. Dengan adanya kontak langsung antara peneliti dengan responden akan menciptakan suatu kondisi yang cukup baik, sehingga responden dengan sukarelakan memberikan data obyektif dan cepat.

Dari beberapa penjelasan diatas dan juga tempat peneliti untuk penelitian ini yang tidak terlalu luas, serta dapat langsung bertemu dengan responden maka peneliti menggunakan kuesioner tertutup, adanya kontak langsung peneliti dan responden dimana peneliti langsung bertatap muka dan bertanya kepada responden dan langsung ditulis jawabannya oleh peneliti.

\section{Dokumen}

Sejumlah besar fakta dan data tersimpan dalam bahan yang berbentuk dokumentasi. Sebagian besar data yang tersedia yaitu berbentuk surat, catatan harian, cendera mata, laporan, artefak, dan foto. Sifat utama data ini tidak terbatas pada ruang dan waktu sehingga memberi peluang kepada peneliti untuk

${ }^{32}$ Dr Juliansyah Noor, S.E., M.M. "Metodologi Penelitian Skripsi, Tesis, Disertasi, dan Karya Ilmiah" (Jakarta, Prenadamedia Group, 2011), 139.

33 Prof. Dr. Sugiyono. "Metode Penelitian Administrasi" (Bandung, Alfabeta, Cetakan ke-23, 2016), 162 mengetahui hal-hal yang pernah terjadi diwaktu silam. Secara detail, bahan dokumenter terbagi beberapa macam, yaitu autobiografi, surat pribadi, buku atau catatan harian, memorial, klipping, dokumen pemerintah atau swasta, data di server dan flashdisk, dan data tersimpan di web site.

Pada penelitian ini dokumen yang akan dijadikan data adalah berbentuk surat, foto, autobiografi, memorial, data di server dan flashdisk serta yang tersimpan diweb site.

\section{Triangulasi}

Dalam teknik pengumpulan data, triangulasi diartikan sebagai teknik pengumpulan data yang bersifat menggabungkan dari berbagai teknik pengumpulan data dan sumber data yang telah ada, bila penelitian peneliti melakukan pengumpulan data dengan triangulasi, maka sebenarnya peneliti mengumpulkan data yang sekaligus menguji kredibilitas data, yaitu mengecek kredibilitas data dengan berbagai teknik pengumpulan data dan berbagai sumber data. ${ }^{34}$

Dalam hal triangulasi, Susan Stainback menyatakan bahwa "the aim is not to determain the truth about some social phenomenon, rather the purpose of triangulation is to increase one's understanding of what ever is being investigated". Tujuan dari triangulasi bukan untuk mencari kebenaran tentang beberapa penomena, tetapi lebih pada peningkatan pemahaman peneliti terhadap apa yang telah ditemukan. Selanjutnya Bogdan menyatakan "what the qualitative research is interesed in is not truth per se, but rather perspective. Thus, rather then trying to determine the "truth" of people's perceptions, the purpose of corroboration is to help researchers increase their understanding and the probability that their finding will be seen as credible of worthy of concideration by others". Tujuan penelitian kualitatif memang bukan semata-mata mencari kebenaran, tetapi lebih pada pemahaman subyek terhadap dunia sekitarnya. Dalam memahami dunia sekitarnya, mungkin apa yang dikemukakan informan salah, karena tidak sesuai dengan teori, tidak sesuai dengan hukum.

selanjutnya Mathinos mengemukakan bahwa "the value of triangulation lies in providing evidence - wether convergent, inconsistent, or contracdictory". Nilai dari teknik pengumpulan data dengan triangulasi adalah untuk mengetahui data yang diperoleh convergent (meluas), tidak konsisten atau kontrakdiksi. Oleh karena itu dengan menggunakan teknik triangulasi dalam pengumpulan data, maka data yang diperoleh akan lebih konsisten, tuntas dan pasti. Melalui triangulasi "can build on the strengths of each type of data collection while minimazing the weakness is any single approach" Patton. Dengan triangulasi akan lebih meningkatkan kekuatan data, bila dibandingkan dengan satu pendekatan. ${ }^{35}$

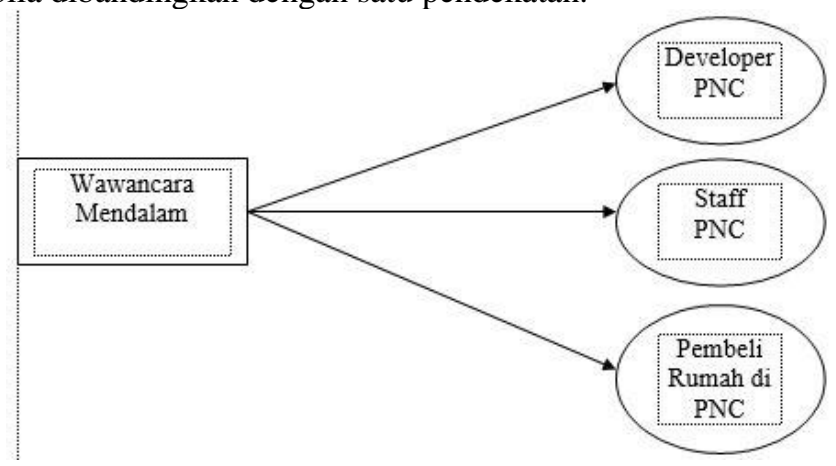

34 Prof. Dr. Sugiyono. "Metode Penelitian Pendidikan Pendekatan Kuantitatif, Kualitatif, dan R\&D” (Bandung, Alfabeta, 2014), 330.

35 Prof. Dr. Sugiyono. "Metode Penelitian Pendidikan Pendekatan Kuantitatif, Kualitatif, dan R\&D” (Bandung, Alfabeta, 2014), 332. 


\section{EKSISBANK Vol. 2 No. 2 Desember 2018}

Gambar 3.3. Triangulasi “ pengumpulan data. (satu teknik pengumpulan data pada bermacam-macam sumber data Developer PNC, Staff PNC, pembeli rumah di PNC)

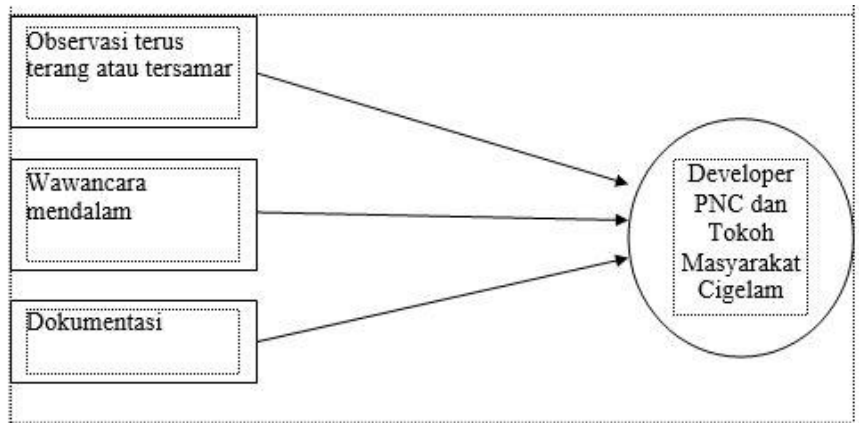

Gambar 3.4. Triangulasi "teknik" pengumpulan data (bermacam-macam cara dengan sumber yang sama)

\subsection{Rancangan Pengolahan dan Analisis Data}

Definisi analisis data menurut Bogdan adalah proses mencari dan menyusun secara sistematis data yang diperoleh dari hasil wawancara, catatan lapangan, dan bahan-bahan lain, sehingga dapat mudah dipahami, dan temuannya dapat diinformasikan kepada orang lain. Analisis data dilakukan dengan mengorganisasikan data, menjabarkanya ke unit-unit, melakukan sintesa, menyusun kedalam pola, memilih mana yang penting dan yang akan dipelajari, dan membuat kesimpulan yang dapat diceritakan kepada orang lain. ${ }^{36}$

Sementara Susan Stainback mengemukakan bahwa "analisis data merupakan hal yang kritis dalam proses penelitian kualitatif. Analisis digunakan untuk memahami hubungan dan konsep dalam data sehingga hipotesis dapat dikembangkan dan di evaluasi”. Spraley (1980) menyatakan bahwa: "Analisis dalam pengertian apapun, adalah merupakan cara berfikir. Hal itu berkaitan dengan pengujian secara sistematis terhadap sesuatu untuk menentukan bagian, hubungan antar bagian, dan hubungannya dengan keseluruhan. Analisis adalah untuk mencari pola.

Analisis data kualitatif adalah bersifat induktif, yaitu suatu analisis berdasarkan data yang diperoleh. Berdasarkan hal tersebut di atas dapat dikemukakan di sini bahwa, analisis data adalah proses mencari dan menyusun secara sistematis data yang diperoleh dari hasil wawancara, catatan lapangan, dan dokumentasi, dengan cara mengorganisasikan data kedalam kategori, menjabarkan ke unit-unit, melakukan sintesa, menyusun kedalam pola, memilih mana yang penting dan yang akan dipelajari, dan membuat kesimpulan sehingga mudah difahami oleh diri sendiri maupun orang lain. ${ }^{37}$

Analisis data pada penelitian inimempunyai beberapa proses, yaitu :

1. Data Reduction (Reduksi Data)

Mereduksi data berarti merangkum, memilih hal-hal yang pokok, memfokuskan pada hal-hal yang pokok, memfokuskan pada hal-hal yang penting, dicari tema dan polanya dan membuang yang tidak perlu. Dengan demikian data yang direduksi akan memberikan gambaran yang lebih jelas, dan memperudah peneliti untuk melakukan pengumpulan data selanjutnya, dan mencarinya bila diperlukan. ${ }^{38}$

36 Prof. Dr. Sugiyono. "Metode Penelitian Pendidikan Pendekatan Kuantitatif, Kualitatif, dan R\&D" (Bandung, Alfabeta, 2014), 334.

37 Prof. Dr. Sugiyono. "Metode Penelitian Pendidikan Pendekatan Kuantitatif, Kualitatif, dan R\&D” (Bandung, Alfabeta, 2014), 335.

38 Prof. Dr. Sugiyono. "Metode Penelitian Pendidikan Pendekatan Kuantitatif, Kualitatif, dan R\&D” (Bandung, Alfabeta, 2014), 338.
Dalam penelitian ini hasil data pada saat dilapangan baik berupa catatan, rekaman suara, dokumentasi, dan berdasarkan data sekunder lainnya akan disatukan, dan direduksi untuk mencari tema/pola agar lebih sesuai dengan tujuan penelitian yang diinginkan.

2. Data Display (Penyajian Data)

Dalam penelitian kualitatif, penyajian data bisa dilakukan dalam bentuk uraian singkat, bagan, hubungan antar kategori, flowchart dan sejenisnya. Dalam hal ini Miles and Huberman menyatakan "yang paling sering digunakan untuk menyajikan data dalam penelitian kualitatif adalah dengan teks yang bersifat naratif'. ${ }^{39}$

Maka, setelah data direduksi kemudian melanjutkan dengan mendisplaykan data (penyajian data) seperti yang dijelaskan diatas peneliti membuat uraian singkat atau naratif yang diungkapkan dari hasil data yang didapatkan sesuai dengan yang dipahami oleh peneliti, dan tidak keluar dari teori-teori yang berkaitan dengan topik-topik penelitian. Selain itu, penyajian data yang berupa bagan, hubungan antar kategori, flowchart dan sejenisnya akan disajikan jika diperlukan dalam pengungkapan data.

3. Counslusion Drawing/verification (Kesimpulan)

Langkah ke tiga dalam analisis data kualitatif menurut Miles and Huberman adalah penarikan kesimpulan dan verifikasi. Kesimpulan awal yang dikemukakan masih bersifat sementara, dan akan berubah bila tidak ditemukan bukti-bukti yang kuat yang mendukung pada tahap pengumpulan data berikutnya. Tetapi apabila kesimpulan yang dikemukakan pada tahap awal, didukung oleh bukti-bukti yang valid dan konsisten saat peneliti kembali ke lapangan mengumpulkan data, maka kesimpulan yang dikemukakan merupakan kesimpulan yang kredibel.

Dengan demikian kesimpulan dalam penelitian kualitatif mungkin dapat menjawab rumusan masalah yang dirumuskan sejak awal, tetapi mungkin juga tidak, karena seperti telah dikemukakan bahwa masalah dan rumusan masalah dalam penelitian kualitatif masih bersifat sementara dan akan berkembang setelah penelitian berada di lapangan. ${ }^{40}$

Kesimpulan dalam penelitian kualitatif yang diharapkan adalah merupakan temuan baru yang sebelumnya belum pernah ada. Temuan dapat berupa deskripsi atau gambaran suatu obyek yang sebelumnya masih remang-remang atau gelap sehingga setelah diteliti menjadi jelas, dapat berupa hubungan kausal atau interaktif, hipotesis atau teori.

Jika dibagankan proses interaktif dalam penelitian ini, alurnya berbentuk seperti gambar berikut:

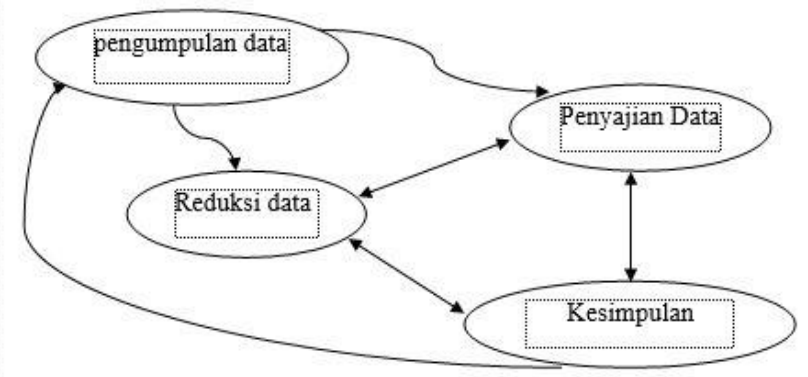

Gambar 3.5. Komponen dalam analisis data Model Miles and Huberman

39 Prof. Dr. Sugiyono. "Metode Penelitian Pendidikan Pendekatan Kuantitatif, Kualitatif, dan R\&D” (Bandung, Alfabeta, 2014), 341.

40 Prof. Dr. Sugiyono. "Metode Penelitian Pendidikan Pendekatan Kuantitatif, Kualitatif, dan R\&D” (Bandung, Alfabeta, 2014), 345. 


\section{Pembahasan dan PenOMENa}

\section{A. Penerapan Margin Murabahah Dalam Akad Pembelian/Pembiayaan Rumah di Puri Nirana Cigelam Purwakarta}

Berdasarkan hasil penelitian dilapangan yang dilakukan dengan teknik pengumpulan data dengan cara wawancara dan dokumen mengenai penerapan margin (keuntungan) dalam akad murabahah yang digunakan di Puri Nirana Cigelam dalam pembiayaan rumah ditetapkan atas dasar kesepakatan yang kedua belah pihak sama-sama menyepakati.

Transaksi akad murabahah yang dilakukan di Puri Nirana Cigelam dengan penerapan margin (keuntungan) yang samasama saling menyepakati menggunakan jenis transaksi murabahah berdasar pesanan dengan model mengikat yaitu penjual atau pihak developer membangun rumah yang telah di pesan oleh pembeli atau konsumen yang mana pembeli atau konsumen tidak bisa membatalkan akad murabahah tersebut.

Dalam menerapkan transaksi murabahah, terutama transaksi yang berdasar pesanan, penjual diperbolehkan untuk meminta uang muka kepada pembeli. Uang muka merupakan bagian pembayaran atas transaksi murabahah yang dilakukan. Pembayaran uang muka oleh pembeli lazimnya dimaksudkan untuk membantu penjual agar dapat memperoleh barang murabahah secara lancar, besaran uang muka ditentukan berdasar kesepakatan penjual dan pembeli. Yang harus mendapat perhatian, besaran uang mukajuga tidakboleh digunakan sebagai faktor untuk menentukan besarnya margin keuntungan yang disepakati. Dengan demikian, pembayaran uang muka semata-mata, dimaksudkan membantu penjual dalam menjalankan transaski murabahah. ${ }^{41}$

Adapun penentuan kesepakatan margin yang diterapkan di Puri Nirana Cigelam dengan beberapa hal, yaitu :

1. Tidak ada patokan dalam penentuan margin (keuntungan), dan PNC sendiri dalam penentuan margin harus dibawah ROI (nilai ketentuan pemerintah dalam hal perumahan pertahun 20\%) penentuan margin di PNC $10 \%$ pertahun, provit ditentukan di awal dan disepakati antara developer dan konsumen.

2. Rataan persaingan dengan suku bunga 7-13\%/9-15\%. Misal untuk konvensional akad langsung disampaikan harga rumah, kemudian untuk margin berdasarkan suku bunga yang berbeda setiap waktu.

Sedangkan syariah menggunakan akad murabahah, harga pokok ditentukan kemudian margin pertahun disepakati $10 \%$ dan diketahuinya harga rumah tersebut dan pembayaran flat (tetap sampai pelunasan) maka keputusan penentuan harga jual beli rumah disepakati.

Seiring dengan berjalannya waktu, serta mengingat kompleknya perkembangan LKI dan produk-produknya, guna penyempurnaan kriteria diatas, Ikatan Akuntan Indonesia (IAI) dalam mengeluarkan Kerangka Dasar Penyusunan dan Penyajian Laporan Keuangan (KDPPLK) Bank Syariah yang diberlakukan mulai tanggal 1 juni 2007, dalam paragraf 27 menetapkan ketentuan karakteristik transaksi syari'ah sebagai berikut $^{42}$ :

1. Transaksi hanya dilakukan berdasarkan prinsip saling paham dan saling ridho

${ }^{41}$ Dr. Sony Warsono bin Hardono, MAFIS, Akuntan. Jufri, SHI, M Hum. “ Akuntansi Transaksi Syari'ah Akad Jual Beli di Lembaga Bukan Bank." (Yogyakarta, Penerbit Asgard Chapter, 2011), 56.
2. Prinsip kebebasan bertransaksi diakui sepanjang objeknya halal dan baik

3. Uang hanya berfungsi sebagai alat tukar dan satuan pengukur nilai, bukan komoditas

4. Tidak mengandung unsur riba

5. Tidak mengandung unsur kezaliman

6. Tidak mengandung unsur maysir

7. Tidak mengandung unsur gharar

8. Tidak mengandung unsur haram

9. Tidak menganut prinsip nila waktu dari uang (time value of money) karena keuntungan yang didapat dalam kegiatan usaha terkait dengan risiko yang melekat pada kegiatan usaha tersebut dengan prinsip al-ghuпmu bil ghurmi (no gain without accompanying risk)

10. Transaksi dilakukan berdasarkan suatu perjanjian yang jelas dan benar serta untuk keuntungan semua pihak tanpa merugikan pihak lain sehingga tidak diperkenankan menggunakan standar ganda harga untuk satu akad serta tidak menggunakan dua transaksi bersamaan yang berkaitan (ta'aaluq) dalam satu akad

11. Tidak ada distorsi harga melalui rekayasa permintaan (najasy), maupun rekayasa penawaran (ikhtikhar)

12. Tidak mengandung unsur kolusi dengan suap-menyuap (risywah)

Sementara pendapat akademisi, meski pemahaman tentang "Murabahah" yang esensinya dapat dikatakan sebagai "Cost Plus Margin", namun masalah penentuan harga jual, khusunya yang berkaitan dengan perhitungan besarnya margin, sebagian masih mentolerir penggunaan "rumus flate rate" dan sejenisnya sebagaimana dipraktikan oleh bank konvensional, sedangkan sebagian yanglain menyatakan bahwa polap erhitungan yang demikian sangat jelas melaksanakan praktik TVM. Sudah banyak pakar keuangan Islam yang menyampaikam tentang diperkenankannya terjadinya perbedaan harga tunai dan harga jual secara kredit. Namun hal ini tidak berarti bahwa marjin penjualan secara kredit mengacu pada banyaknya/jumlah satuan waktu (hari, bulan atau tahun) dalam perioda pembayaran Murabahah. Misal ditentukan besarnya margin sebanyak $10 \%$ pertahun, sehingga untuk pembiayaan Murabahah selama tiga tahun, maka marginnya adalah 30\% (3 tahun $\mathrm{x} 10 \%$ ). Jika hal ini diikuti, maka sama halnya dengan perhitungan bunga atas kredit/pinjaman pada bank/lembaga keuangan konvensional. ${ }^{43}$

Berdasarkan hasil penelitian di Puri Nirana Cigelam mengenai penetapan margin yang sudah ada perhitungannya diatas, Puri Nirana Cigelam mengenai pembiayaan rumah besaran marginnya tidak $10 \%$ pertahun. Meskipun pada saat akad disampaikan dan disepakati bahwa penetapan margin adalah $10 \%$. Maka dengan begitu Puri Nirana Cigelam bebas dari riba.

\section{B. Kendala Dalam Penetapan Margin di Puri Nirana Cigelam Purwakarta}

Berdasarkan dari penelitian yang dilakukan dilapangan dengan teknik pengumpulan data dengan observasi, wawancara dan angket mengenai penetapan margin menurut developer sendiri dalam satu tahun setengah Puri Nirana Cigelam berjalan

\footnotetext{
${ }^{42}$ Sugeng Widodo," Seluk Beluk Jual Beli Murabahah Persfektif Aplikatif". (Yogyakarta, Penerbit Asgard Chapter, 2010), 33.

${ }^{43}$ Sugeng Widodo," Seluk Beluk Jual Beli Murabahah Persfektif Aplikatif". (Yogyakarta, Penerbit Asgard Chapter, 2010), 35.
} 


\section{EKSISBANK Vol. 2 No. 2 Desember 2018}

melakukan akad murabahah dalam jual beli rumah dengan kesepakatan margin yang disepakati bersama antara developer dan konsumen dan selama ini pun tidak ada kendala dalam penetapan margin. Berdasarkan wawancara dan angket konsumen menyepakati penetapan margin, dengan penetapan margin yang lebih kecil dibandingkan perumahan lain yang mengikuti suku bunga, konsumenpun menyepakati karena dalam akad jual beli dan penetapan margin di Puri Nirana Cigelam tanpa riba.

Adanya kesepakatan penetapan margin (keuntungan) antara pihak pertama yaitu developer (penjual) dan pihak kedua yaitu konsumen (pembeli), maka dalam penetapan margin (keuntungan) di Puri Nirana Cigelam tidak ada kendala sama sekali.

\section{Upaya Penerapan Implementasi Akad Murabahah Pada Pembiayaan Rumah Non Bank di Puri Nirana Cigelam Purwakarta}

Fatwa Dewan Syari'ah Nasional no.04/DSN-MUI/IV/2000 tentang akad murabahah. Menimbang :

1. Bahwa masyarakat banyak memerlukan bantuan penyaluran dana dari bank berdasarkan prinsip jual beli

2. Bahwa dalam rangka membantu masyarakat guna melangsungkan dan meningkatkan kesejahteraan dan berbagai kegiatan, bank syariah perlu memiliki fasilitas murabahah bagi yang memerlukannya, yaitu menjual suatu barang dengan menegaskan harga belinya kepada pembeli dan pembeli membayarnya dengan harga yang lebih sebagai laba

3. Bahwa oleh karena itu, DSN perlu menetapkan fatwa tentang Murabahah untuk dijadikan pedoman oleh bank syari'ah.

Berdasarkan hasil penelitian dilapangan dan membaca teori yang dijadikan referensi dalam skripsi ini, adanya fatwa murabahah untuk dijadikan pedoman oleh bank syari'ah yaitu agar jual beli bebas dari riba, apa yang dijual belikan tidak diharamkan oleh syari'ah Islam, jika bank hendak mewakilkan kepada nasabah untuk membeli barang atau rumah dari pihak ketiga, akad jual beli murabahah harus dilakukan setelah barang secara prinsip menjadi milik bank, serta akad murabahah ini sesuai dasar hukum yang berlandaskan dari Alqur'an dan As-sunnah dimana kedua belah pihak suka sama suka atau ridho dalam melakukan akad murabahah.

Implementasi akad murabahah yang dilakukan oleh Puri Nirana Cigelam Purwakarta dengan cara non bank, yaitu pihak developer atau penjual rumah melakukan jual beli tanpa adanya pemasok modal dari bank, maka developer dan konsumen langsung melakukan akad murabahah dan transaksi pembayaranpun langsung kepada pihak developer. Cara transaksi non bank yang telah dilakukan bertujuan membantu masyarakat guna melangsungkan dan meningkatkan kesejahteraan dan berbagai kegiatan untuk memotivasi dalam melakukan setiap jual beli atau usaha tidak mesti harus selalu meminta bantuan bank dalam hal modal usaha.

Beberapa hal yang didapatkan dari hasil penelitian tentang upaya apa saja yang dilakukan dalam penerapan implementasi akad murabahah pada pembiayaan rumah non bank di Puri Nirana Cigelam, terbagi dalam lima upaya yaitu :

1. Promosi perumahan syariah Puri Nirana Cigelam

2. Persyaratan pengajuan KPRS Puri Nirana Cigelam

3. Edukasi konsep perumahan syariah Puri Nirana Cigelam
4. Penerapan akad murabahah pada pembiayaan rumah non bank di Puri Nirana Cigelam

5. Strategi dalam menghadapi pembiayaan bermasalah di Puri Nirana Cigelam.

Lima poin upaya dalam penerapan implementasi akad murabahah pada pembiayaan rumah non bank di Puri Nirana Cigelam dijelaskan dalam poin-poin sebagai berikut :

\section{Promosi Perumahan Syariah Puri Nirana Cigelam}

Strategi Promosi adalah tindakan perencanaan, implementasi, dan pengendalian komunikasi dari organisasi kepada pelanggan dan audiens sasaran (target audiences) lainnya. Strategi promosi mengkombinasikan periklanan (advertising), penjualan personal (sales promotion), publisitas dan hubungan masyarakat (publicity and public relation), dan pemasaran langsung (direct marketing) dalam suatu program terkoordinasi untuk berkomuniakasi dengan pembeli dan pihak lainnya yang mempengaruhi keputusan pembelian. Aktivitas promosi memberikan pengaruh yang penting untuk keberhasilan penjualan perusahaan.

Promosi digunakan untuk memberikan informasi kepada orang-orang tentang produk dan mempersuasi pembeli/target pasar, saluran distribusi, dan publik untuk membeli mereknya. Masing-masing bentuk promosi memiliki kekuatan dan kelemahannya sehingga diperlukan strategi yang terintegrasi untuk dapat meningkatkan kekuatan masing-masing komponen dalam berpromosi dan mendesai bauran promosi yang efektif dan efisien. ${ }^{44}$

Berdasarkan dari hasil penelitian lapangan promosi bertujuan untuk memperkenalkan keberadaan Puri Nirana Cigelam kepada masyarakat, memperkenalkan konsep perumahan dan value syariah serta akad tanpa bank, tanpa riba, tanpa denda, tanpa sita dan tanpa akad bermasalah

Promosi dilakukan oleh pihak marketing dengan dibagi dua tim yaitu tim online dan tim off line. Tim online menggunakan media sosial yaitu web site, Facebook (Facebook add dan fanpage), twitter, instagram, youtube, copy writing (tulisan yang disebarkan yang mengandung nilai jual) dan hampir $80 \%$ promosi menggunakan dengan media sosial. Sedangkan tim offline mempromosikan Property Syariah Puri Nirana Cigelam dengan menyebar brosur, siaran di radio dan televisi.

\section{E. Persyaratan Pengajuan KPR Syariah Puri Nirana Cigelam}

Pengajuan atau permohonan Kredit Perumahan Syariah (KPRS) memiliki beberapa persyaratan yaitu untuk mengisi data calon konsumen guna menyeleksi lolos atau tidak dalam pengajuan atau permohonan KPRS tersebut.

Berdasarkan hasil penelitian Persyaratan Pengajuan KPRS terbagi menjadi dua jenis yaitu persyaratan untuk karyawan swasta atau BUMN atau PNS dan persyaratan untuk pengusaha atau wiraswasta, adapun persyaratannya adalah sebagai berikut:

Persyaratan Pengajuan KPR Syariah untuk Karyawan Swasta/ BUMN/ PNS :

1. FC KTP suami istri

2. FC Kartu Keluarga

3. FC Akta/ Buku Nikah

4. FC NPWP

5. FC SK Pengangkatan/Surat Keterangan Kerja 
6. Slip gaji tiga bulan terakhir

7. FC agunan pengganti (untuk skema KPR Syariah)

8. Pas Foto berwarna ukuran $3 \times 4$ (suami istri)

Persyaratan Pengajuan KPR Syariah

untuk

Pengusaha/Wiraswasta :

1. FC KTP suami istri

2. FC Kartu Keluarga

3. FC Akta/ Buku Nikah

4. FC NPWP

5. FC SIUP/TDP

6. FC Rekening Tabungan tiga bulan terakhir

Terkait dengan cara pembayaran, murabahah lazimnya dilakukan dengan menggunakan salah satu dari beberapa metoda pembayaran berikut ini $^{45}$ :

1. Pembayaran tunai

2. Pembayaran ditangguhkan tanpa agunan dengan pelunasan sekaligus

3. Pembayaran ditangguhkan tanpa agunan dengan pelunasan angsuran

4. pembayaran ditangguhkan yang disertai agunan dengan pelunasan sekaligus

5. pembayaran ditangguhkan yang disertai agunan dengan pelunasan angsuran

6. pembayaran uang muka

Murabahah yang pembayarannya ditangguhkan pada dasarnya dapat dianalogikan dengan transaksi jual beli di bisnis konvensional tetapi tidak terdapat perhitungan bunga didalamnya. Murabahah dengan pembayaran ditangguhkan dapat bersifat pendek (jika periode kurang dari 1 periode akuntansi) maupun bersifat jangka panjang (jika periode lebih dari 1 periode akuntansi).

Secara syari'ah, metoda pembayaran tidak boleh digunakan sebagai faktor untuk menentukan besarnya harga kesepakatan karena transaksi syari'ah melarang penggunaan prinsip nilai waktu uang yang berisiko terjadi praktik riba.

Berdasarkan penelitian dilapangan Puri Nirana Cigelam menggunakan metoda pembayaran tunai, Pembayaran ditangguhkan tanpa agunan dengan pelunasan angsuran, pembayaran ditangguhkan yang disertai agunan dengan pelunasan angsuran.

\section{F. Edukasi Konsep Perumahan Syariah Puri Nirana Cigelam}

Berdasarkan hasil penelitian dengan menggunakan teknik pengumpulan data wawancara secara mendalam dengan pihak Puri Nirana Cigelam, peneliti dapat menyimpulkan tujuan edukasi ini yaitu agar konsumen dapat memahami tentang akad dan konsep yang diterapkan di Puri Nirana Cigelam serta fasilitas-fasilitas yang disediakan. Peneliti pun mendapatkan poin-poin edukasi yang selama ini dilaksanakan dalam proses seleksi calon konsumen dalam jual beli rumah yang dilakukan dengan akad murabahah. Poin-poin edukasi itu yaitu :

\section{Penyampaian bahaya riba}

Dari Jabir ra berkata, bahwa Rasulullah SAW melaknat orang yang memakan riba, orang yang memberikannya, penulisnya dan dua saksinya, dan beliau berkata, mereka semua adalah sama. (HR. Muslim). Begitulah, kita yang tidak ikut memakan riba tetapi juga berdosa karena sebagai penyetornya, dan kedudukan atau dosa penyetor dan pemakan riba adalah sama.

Bahkan dosa yang paling ringan dari praktek riba ini adalah seperti kita berzina dengan ibu sendiri, sebagaimana sebuah hadist : "Dari Abdullah bin Mas'ud ra, bahwa Rasulullah SAW bersabda, "Riba itu tujuh puluh tiga pintu, dan pintu yang paling ringan dari riba adalah seperti seorang lelaki yang berzina dengan ibu kandungnya sendiri." (HR. Hakim, Ibnu Majah dan Baihaqi). Kita pun pasti merasa jijik ketika mendengar kata ( maaf) babi. Karena keharamannya, sehingga apapun yang berhubungan dengan babi akan ditolak bahkan diboikot. Ini adalah hal positif yang menunjukkan kehati-hatian sikap seorang muslim dalam hal makanan.

Seharusnya kita pun juga melakukan kehati-hatian yang sama dalam hal riba ini, mengingat dosa riba lebih besar dari memakan daging babi. Sebesar-besarnya dosa memakan daging babi masih tidak disebut oleh Allah Subhanahuata'ala sebagai berperang dengan-Nya, Karena jika ada orang yang masih ngotot melakukan praktik riba dengan berbagai dalih, maka sebenarnya mereka seperti mengajak perang dengan Allah dan Rasul-Nya ( Al Baqarah 278-279), dan mereka kekal di dalam neraka ( Al Baqarah 275 )

\section{Penyampaian akad-akad dalam Islam}

Pembeli yang mengalami gagal bayar akan diberikan solusi syariah bukan sita. Sita dan kemudian dilelang sering diberlakukan di KPR Konvensional. Saat di sita pembeli tidak mendapatkan hak yang semestinya. DP dan cicilan sekian tahun dianggapnya hangus. Sehingga skema ini mengandung dua akad. Akad pertarna sewa menyewa dan yang kedua adalah jual-beli. Akad pertarna berlangsung sebelum lunasnya cicilan dan akad kedua pas pelunasan cicilan. Padahal Islam melarang adanya dua akad dalam satu transaksi. ${ }^{46}$

Di Puri Nirana Cigelam menggunakan akad murabahah dimana akadnya langsung akad jual beli dan sertifikat rumahpun diserahkan kepada pemilik rumah setelah DP lunas dan pembangunan rumah 8 bulan.

\section{G. Keuntungan membeli perumahan Puri Nirana Cigelam}

1. Value Syariah memastikan anda terbebas dari jerat Riba

2. Dengan konsep KPR Syariah anda terbebas dari Riba, Denda, Sita dan Akad Bermasalah.

3. Gratis biaya KPR, seperti administrasi penalty dll

4. Fasilitas umum yang memadai seperti : Playground, Mini Sport Center, Taman, Gazebo, Row hingga 10 meter.

5. One Gate System, dengan system keamanan 24 jam.

6. Lokasi Premium dekat dengan pusat kota, Kawasan Industri, Mall, Pasar Induk Modern, Rumah Sakit, Lembaga Pendidikan.

7. Lokasi Strategis dekat dengan pintu tol Sadang, Cikopo dan Kalihurip.

8. Kawasan Hutan Lindung menjadikan Puri Nirana Cigelam berkonsep hijau dan asri.

9. Puri Nirana Cigelam beralamatkan di Jl. Alternatif Sadang-BIC, Desa Cigelam, Babakan Cikao, Purwakarta.

10. Harga akad sudah jelas diawal

11. Cicilan flat tidak mengikuti suku bunga

12. Insyaa Allah berpahala karena berusaha menjauhi riba

${ }^{45}$ Dr. Sony Warsono bin Hardono, MAFIS, Akuntan. Jufri, SHI, M Hum. “ Akuntansi Transaksi Syari'ah Akad Jual Beli di Lembaga Bukan Bank." (Yogyakarta, Penerbit Asgard Chapter, 2011), 55. 
13. Hati tenang, tentram tidak khawatir suatu saat rumahnya sita

14. Investasi aman dunia akhirat

15. Jika mengambil cicilan 5 tahun, 7 tahun atau 10 tahun dan ternyata misal mengambil cicilan yang 10 tahun ternyata pada saat ke 5 tahun Allah memberikan rezeki lebih bisa langsung di lunasi tanpa finalti.

\section{H. Penerapan Akad Murabahah Pada Pembiayaan Rumah Non Bank Puri Nirana Cigelam}

Dalam penerapan akad murabahah pada pembiayaan rumah non bank di Puri Nirana Cigelam Purwakarta, berdasarkan hasil penelitian lapangan akad murabahah terjadi apabila konsumen dinyatakan lolos setelah melakukan beberapa tahap. Adapun beberapa tahap dalam penerapan akad murabahah yang dilakukan, yaitu :

1. Konsumen sudah melengkapi persyaratan yang telah ditetapkan

2. Closing (berkas lengkap) sudah di skrining awal kemudian disaring dan lolos

3. Lolos dari analisis kredit untuk skema KPR Syariah kredit

4. Lolos dari tim survey independen.

Setelah 4 poin diatas dinyatakan lolos konsumen dengan pihak developer melakukan pertemuan untuk melakukan akad murabahah, harga ditentukan di awal dan sama-sama menyepakati, developer menyampaikan harga kemudian margin yang akan disepakati bersama. Setelah akad murabahah pada pembiayaan rumah disepakati konsumen dan developer menandatangani surat pernyataan telah melakukan akad murabahah, kemudian pembayaran angsuran tiap bulan langsung dikirim ke pihak developer. Puri Nirana Cigelam memiliki BMT dan setiap konsumen menjadi nasabah BMT tersebut hanya posisi BMT disini bukan sebagai pihak ketiga karena pembayaran angsuran/kewajiban rumah tiap bulan langsung dibayarkan kepada developer baik cash atau via transfer Bank Muamalat.

Posisi BMT yang ada di Puri Nirana Cigelam yaitu divisi resmi untuk persyaratan mengeluarkan fasilitas kredit, divisi resmi yang disarankan oleh pihak keuangan Puri Nirana Cigelam untuk mempermudah pengelola dan laporan keuangan pembayaran secara angsuran.

Tahap-tahap yang dilalui oleh konsumen kemudian dinyatakan lolos dalam pengajuan atau permohonan KPRS, untuk agunan pengganti sebagai syarat skema kredit perumahan syariah disimpan dikantor pemasaran Puri Nirana Cigelam. Pada saat melakukan akad konsumen menandatangani akad murabahah yang harga jual rumah diketahui, diketahui jumlah down payment (DP) dan kesepakatan penetapan margin (keuntungan). Penentuan penggajuan KPRS dalam menentukan jangka waktu cicilan rumah ditetapkan sesuai dengan penghasilan perbulan yang dibebankan kepada konsumen tidak lebih dari 50\%. Down payment (DP) dalam akad murabahah ini dapat dilakukan tunai atau dengan angsuran selama 12 bulan.

Jual beli rumah yang menggunakan akad murabahah di Puri Nirana Cigelam menggunakan jenis transaksi akad murabahah pesanan yaitu rumah dibangun setelah down payment (DP) lunas, saat pembangunan pada bulan ke delapan rumah resmi diserahterimakan atau pemindahtanganan dari developer ke

47 Prof. Dr Sutan Remy Sjahdeini, S.H "Perbankan Syariah, Produk produk dan Aspek-aspek Hukumnya" (Prenadamedia Group, 2014) konsumen. Rumah menjadi hak milik konsumen, sesuai dengan syarat jual beli yaitu barang yang diperjualbelikan harus dapat dipindahtangankan hak kepemilikannya. Hal ini terkait dengan peralihan hak kepemilikan tersebut dari penjual kepada pembeli ketika transaksi jual beli terjadi dan selesai dilakukan. kemudian hak kepemilikan atas barang yang diperjualbelikan tersebut harus secara yuridis beralih kepada pembeli dengan konsekuensi bahwa dengan beralihnya hak kepemilikan ini maka beralih pula segala resiko yang dapat timbul terhadap barang itu, misalnya risiko kerusakan, kecurian, ketinggalan zaman dan turunnya harga. ${ }^{47}$

\section{Strategi Dalam Menghadapi Pembiayaan Bermasalah di Puri Nirana Cigelam}

Berdasarkan hasil penelitian dilapangan dalam mengahadapi pembiayaan bermasalah maka pihak Puri Nirana Cigelam memiliki beberapa strategi, strategi menurut Hunger dan Wheelen adalah serangkaian keputusan dan tindakan manajerial yang menentukan kinerja perusahaan dalam jangka panjang. Pembiayaan bermasalah atau cidera janji, langkahlangkah atau kebijakan yang diambil yaitu :

1. Memantau dan mengingatkan

2. Tabayyun

3. Musyawarah

4. SP 1

5. SP 2

6. Diberikan waktu 30 hari untuk bisa melunasi kewajiban angsuran rumah

7. Jika msih belum membayar di berikan waktu tambahan 15 hari

8. Dan jika masih belum membayar diberikan waktu tambahan lagi 10 hari

9. Setelah itu jika masih belum bisa membayar kewajiban angsuran rumah maka diberikan pilihan apakah rumah yang dimiliki di Puri Nirana Cigelam akan dijual untuk membayar cicilan yang belum terbayar, kemudian jika masih ada sisa maka diberikan kepada konsumen atau memilih menjual agunan pengganti untuk membayar kewajiban angsuran rumah di Puri Nirana Cigelam dan jika ada sisa maka uangpun dikembalikan kepada konsumen.

Tugas ini dilakukan oleh divisi kolektor debitur/admin pembiayaan in house (internal). Proses penjualan rumah di Puri Nirana Cigelam Purwakarta menggunakan POAC (planning, organizing, actuating, dan controling). Planning menyusun strategi pemasaran bersama perpriode, organizing menyusun awal project SDM yaitu membagi tim promosi, actuating yaitu penyampaian edukasi dan promosi, dan controling adanya evaluasi sistem dan mantanence kepada konsumen yang sudah closing. ${ }^{48}$

Berdasarkan hasil penelitian dilapangan dari teori yang diambil yaitu teori $6 \mathrm{C}$ (Character, Capital, Capacity, Colleteral, Condition off Economy dan Constraints) pihak Puri Nirana Cigelam melakukan teori tersebut dalam upaya pemilihan konsumen dalam pembiayaan rumah.

\section{KESIMPULAN}

Berdasarkan hasil penelitian mengenai "Implementasi Akad Murabahah Pada Pembiayaan Rumah Non Bank Di Puri Nirana Cigelam Purwakarta" yang dilakukan melalui observasi,

${ }^{48}$ Wawancara dengan Bapak Rudi Miftah manager marketing in house, senin 29-09-2017 pukul 11.00-12.00 WIB 


\section{EKSISBANK Vol. 2 No. 2 Desember 2018}

wawancara, angket, dokumentasi serta triangulasi atau gabungan. Penulis menemukan empat unsur yang dapat ditarik dari skripsi ini, penulis pun menyimpulkan empat buah kesimpulan antara lain:

1. Pentepan margin dalam akad murabahah berdasarkan kesepakatan, kesepakatannya adalah 10\%, pada realitasnya margin yang didapatkan pada setiap tahun kurang dari $10 \%$.

2. Tidak ada kendala dalam penetapan margin dalam akad murabahah yang telah diimplementasikan di Puri Nirana Cigelam, karena pada saat penandatanganan akad developer (penjual) dan konsumen sama-sama sepakat dan ridho dalam penentuan harga dan margin (keuntungan).

3. Mekanisme pembiayaan rumah non bank Puri Nirana Cigelam Purwakarta memiliki beberapa tahapan yaitu pengajuan permohonan dan kelengkapan persyaratan, edukasi dari pihak Puri Nirana Cigelam kepada konsumen menyampaikan tentang perumahan syariah yang dikonsep dengan value syariah yaitu tanpa bank, tanpa riba, tanpa denda, tanpa sita, tanpa akad bermasalah. Menggunakan akad murabahah sebagai transaksi jual beli rumah, sesuai dengan FATWA DEWAN SYARI'AH NASIONAL NO.04/DSN-MUI/IV/2000 tentang murabahah. Akad jual beli barang dengan menegaskan harga belinya kepada pembeli dan pembeli membayarnya dengan harga yang lebih sebagai laba. Serta survei kepada calon pembeli oleh tim survei independen. Setelah semua tahapan dilalui dan dikatakan lolos pengajuan permohonan maka selanjutnya adanya negosiasi dan kesepakatan penentuan harga dalam pembiayaan rumah dengan skema Kepemilikan Perumahan Syariah (KPRS). Dalam penentuan harga dan jangka waktu pembayaran KPRS ditentukan oleh besar kecilnya penghasilan konsumen. Dalam skema KPRS adanya persyaratan memiliki agunan baik berupa tanah, tanah dan bangunan ataupun kendaraan yang nilainya lebih dari 100 juta.

4. Implementasi akad murabahah dalam pembiayaan rumah non bank di Puri Nirana Cigelam yaitu penandatangan akad kedua belah pihak anatara developer yang menjual rumah dan konsumen yang membeli rumah dengan kejelasan harga dan pembayaran secara flat serta penentapan margin atau keuntungan yang kedua belah pihak sama-sama menyepakati.

5. Respon konsumen terhadap implementasi akad murabahah di Puri Nirana Cigelam banyak yang menyatakan setuju dan bagus, dengan begitu keberadaan Puri Nirana Cigelam, akad yang diterapkan di Puri Nirana Cigelam, Konsep Islami dan Value Syari'ah serta fasilitas-fasilitas yang diberikan oleh pihak PNC adalah alasan konsumen memilih membeli perumahan di Puri Nirana Cigelam.

\section{REFERENSI}

[1] S. M. Metev and V. P. Veiko, Laser Assisted Microtechnology, 2nd ed. R. M. Osgood, Jr., Ed. Berlin, Germany: Springer-Verlag, 1998.

[2] J. Breckling, Ed., The Analysis of Directional Time Series: Applications to Wind Speed and Direction, ser. Lecture Notes in Statistics. Berlin, Germany: Springer, 1989, vol. 61.

[3] S. Zhang, C. Zhu, J. K. O. Sin, and P. K. T. Mok, "A novel ultrathin elevated channel low-temperature poly-Si TFT," IEEE Electron Device Lett., vol. 20, pp. 569-571, Nov. 1999.

[4] M. Wegmuller, J. P. von der Weid, P. Oberson, and N. Gisin, "High resolution fiber distributed measurements with coherent OFDR," in Proc. ECOC'00, 2000, paper 11.3.4, p. 109

[5] R. E. Sorace, V. S. Reinhardt, and S. A. Vaughn, "High-speed digitalto-RF converter," U.S. Patent 5668 842, Sept. 16, 1997.

[6] (2002) The IEEE website. [Online]. Available: http://www.ieee.org/

[7] M. Shell. (2002) IEEEtran homepage on CTAN. [Online]. Available: http://www.ctan.org/texarchive/macros/latex/contrib/supported/IEEEtran/

[8] FLEXChip Signal Processor (MC68175/D), Motorola, 1996.

[9] "PDCA12-70 data sheet," Opto Speed SA, Mezzovico, Switzerland.

[10] A. Karnik, "Performance of TCP congestion control with rate feedback: TCP/ABR and rate adaptive TCP/IP," M. Eng. thesis, Indian Institute of Science, Bangalore, India, Jan. 1999.

[11] J. Padhye, V. Firoiu, and D. Towsley, "A stochastic model of TCP Reno congestion avoidance and control," Univ. of Massachusetts, Amherst, MA, CMPSCI Tech. Rep. 99-02, 1999.

[12] Wireless LAN Medium Access Control (MAC) and Physical Layer (PHY Specification, IEEE Std. 802.11, 1997. 